\title{
Anti-inflammatory activity in vitro and in vivo of ethanolic extracts of Stevia rebaudiana Bertoni and Trigonella foenum-graecum
}

\author{
${ }^{1}$ Medhat I.A.E., ${ }^{2}$ Gamal Fakhry, ${ }^{1}$ Khalifa Y. M. and ${ }^{3}$ Haredy. H. H. \\ ${ }^{1}$ Agronomy, Fac. Agric., Al-Azhar Univ., Assuit Branch, ${ }^{2}$ Biochemistry Department, Fac. Agric., Minia \\ University, ${ }^{3}$ Pharmacology, Fac. of Medicine, Al-Azhar Univ., Assuit Branch
}

Accepted on: 1/12/2020

\begin{abstract}
This study was based on evaluating anti-inflammatory activity of ethanolic extracts from Stevia leaves (EESL) and Fenugreek seeds (EEFS) (in vitro and in vivo). In the in vitro experiment, the results exhibited potent antiinflammatory activity. The combination of both extracts $(1: 1,100 \mu \mathrm{g})$ showed to be the most potent inhibitor of COX-2 with inhibition \% (83.64\%). This result was comparable with the standard Celecoxib showed higher level of inhibition, $(86.63 \%, 100 \mu \mathrm{g})$. While, EESL showed the highest activity as COX-1 inhibitory activity $(74.35 \%, 100 \mu \mathrm{g})$, which it is higher than standard Celecoxib $(67.64 \%, 100 \mu \mathrm{g})$. In vivo anti-inflammatory activity was performed on Wistar rats at the doses 200 and $400 \mathrm{mg} / \mathrm{kg}$ body weight using the carrageenan-induced rat paw edema modal. Combination of (SLEE + FSEE, each $100 \mathrm{mg})$ displayed the highest significant anti-inflammatory activity $\left(0.46^{\mathrm{ef}} \pm 0.025, p<0.05\right)$ after $4 \mathrm{~h}$, compared with indomethacin $\left(0.44^{\mathrm{f}} \pm 0.025, p<0.05\right)$. The results indicated that these plants may have a role for discovering new anti-inflammatory natural drugs. Furthermore, Stevia leaves and Fenugreek seeds can be subjected to further investigations as anticancer agents.
\end{abstract}

KEYWORDS: Anti-inflammatory, COX-1, COX-2-isozyme, fenugreek- Stevia.

\section{INTRODUCTION}

Inflammation is known, as the Localized response of living mammalian tissue to injury due to a factor and exhibit in the shape of painful tumefy associated with some skin changes (Arya et al., 2012). On the other side, the available antiinflammatory medications present a loose range of aspect effects for which the primary reason is nonselective repression of COX- I and (COX-II) (Vane and Botting, 1995). The inflammation response happens in two stages meaning, the emission or liberation of histamine, serotonin, and bradykinin in the first stage, and followed by prostaglandin liberation in the second stage (Deraedt et al., 1976). The carrageenan-induced paw edema shape is widely used for determining the critical stage of the inflammatory. Histamine, 5hydroxytryptamine, and bradykinin are the first detectable mediators in the Initial stage of carrageenan-induced inflammation, whilst prostaglandins are tangible in the final stage inflammation (Jain et al., 2010).

The medical herbs are in persistent need in the developed world for initial health care for their efficacy, safety, and few side effects. These plants are rich as secondary metabolites and involved triterpenes, sterols, and alkaloids others. Many of these phyto-components showed different biological activities viz., antidiabetic, wound healing activities
(Assaf et al., 2019), antimicrobial (Mahmoud et al., 2019), anti-inflammatory and anti-hyperglycemia (Mohammed et al., 2016), hepatoprotective (Wahid et al., 2016). etc.

Stevia rebaudiana Bertoni, (Family: Asteraceae), Known for its abundance as the sweet leaves, is an herbaceous perennial shrub. source is in South America, it is widely cultivated and used mostly as a sweetener in many parts of the world, including Central America, Paraguay, Thailand, China, and Bangladesh (Gupta et al., 2013). Besides its sweetening property, Stevia rebaudiana is also known for its medicinal properties (Debnath, 2008).

Fenugreek (Trigonella foenum-graecum L.), are family Fabaceae has a long and esteemed history history of medicinal uses in Middle East and Persian medicine. The hypocholesterolaemic and hypoglycaemic effect of fenugreek were attributed to its major steroidal sapogenin, diosgenin and its major alkaloid (trigonelline). (Mehrafarin et al., 2010). anti-inflammatory activiteis of methanolic extract of callus and intact plant part of stevia rebaudiana Bertoni were studied for the first time (Arya et al., 2012).

Stevia leaves and fenugreek seeds contains fiber, alkaloids, flavonoids, phenolic compounds, saponins and steroids (Mahmood and Yahya, (2017); Howlader et al., 2016).

The current work Seeks to study the antiinflammatory activities of ethanolic extracts of both 
Stevia leaves (SLEE) and Fenugreek seeds (FSEE) in vitro and in vivo.

\section{MATERIAL AND METHODS}

\subsection{Plant material:}

\subsubsection{Stevia plant:}

The leaves of stevia plants (Stevia rebaudiana Bertoni), were obtained from Sugar Crops Research Institute, Agricultural Research Centre, Giza, Egypt. The leaves were removed from the plants, washed with water, and dried at room temperature $25-30{ }^{\circ} \mathrm{C}$.

\subsubsection{Fenugreek plant:}

Seeds of Trigonella foenum graecum were provided kindly rom Prof. Dr. Gamal Abdel Aziz professor in Research Institute, Agricultural Research Centre, Giza, Egypt.

\subsection{Preparation of ethanolic extracts:}

Finely ground the Stevia leaves and Fenugreek seeds. Each sample $(100 \mathrm{~g})$ was soaked separately in 1 liter of ethyl alcohol at a ratio of (1:10) in a closed flask for $24 \mathrm{~h}$. Then, they were quickly filtered with precautions against the loss of solvent. The ethanolic extracts were concentrated for drying in a rotary evaporator under low pressure and controlled temperature $\left(40-50{ }^{\circ} \mathrm{C}\right)$ to yield Stevia leaves (39.92 g, SLEE) and Fenugreek (16.53 g, FSEE). The ethanolic extracts were stored in the refrigerator at $4{ }^{\circ} \mathrm{C}$ until further use.

\subsection{Anti-Inflammatory activity:}

\subsubsection{In vitro cyclooxygenase inhibition action:}

The colorimetric COX (ovine) method by (Ghorab et al., 2017).

\subsubsection{In vivo carrageenan induced paw edema}

Fifty-four Male adult albino rats (150-200 g) were obtained from the animal house of Faculty of Medicine, Assiut University, Egypt and used for antiinflammatory studies. They were housed at the temperature $24 \pm 2^{\circ} \mathrm{C}$ in groups of six animals each group. The fasted of animals were over night before the experiment (Kulkarni, 2007). The antiinflammatory activity method by (Perez et al. 1990).

\section{Experimental design:}

Rats were divided into 9 groups (6 rats each) as following:

Group 1: Normal (distilled water).

Group 2: Carrageenan (injection of Carrageenan).

Group 3: Carrageenan + (Standard drug Indomethacin $7 \mathrm{mg} / \mathrm{kg}$ b.wt) Yazdinezhad and Andalib, (2017) revealed that the indomethacin decrease inflammation. The rats were treated with indomethacin at a dose of $10 \mathrm{mg} / \mathrm{kg}$ (Mondal et al., 2019).

Group 4: Carrageenan + (SLEE $200 \mathrm{mg} / \mathrm{kg}$ b.wt).

Group 5: Carrageenan + (SLEE $400 \mathrm{mg} / \mathrm{kg}$ b.wt).

Group 6: Carrageenan + (FSEE $200 \mathrm{mg} / \mathrm{kg}$ b.wt).

Group 7: Carrageenan + (FSEE $400 \mathrm{mg} / \mathrm{kg}$ b.wt).

Group 8: Carrageenan + (Combination of (SLEE + FSEE, each $100 \mathrm{mg} / \mathrm{kg}$ b.wt).

Group 9: Carrageenan + (Combination (SLEE + FSEE, each $200 \mathrm{mg} / \mathrm{kg}$ b.wt).

Indomethacin and ethanolic extracts were injected with a single dose at $0,1,2,3$ and $4 \mathrm{~h}$ after the carrageenan injection.

The percentages of edema inhibition were calculated according to the following equation (Arya et al., 2012).

\section{Percentage of Inhibition}

$$
=\frac{(V T-V O) \text { Control }-(V T-V O) \text { Treated group }}{(V T-V O) \text { Control }} \times 100
$$

$\mathbf{V}_{\mathbf{0}}=$ paw volume of the rat before administration of Carrageenan.

$\mathbf{V}_{\mathbf{T}}=$ paw volume of the rat after the administration of Carrageenan at different time intervals. Percentage inhibition of paw edema was found to be proportional to anti-inflammatory activity.

\subsection{Statistical analysis}

The outcomes were considered in mean \pm SD. One-way variance analysis (ANOVA) followed by Dunnett's test, using SPSS 13.0, The findings were considered as statistically significant at the level of $p<0.05$.

\section{RESULTS AND DISCUSSION}

\subsection{In vitro anti-inflammatory activity:}

Among all sample as cyclooxgenase-II (COX-2) inhibitory percentage activity at $100 \mathrm{~g}$, the combination of (SLEE 50\% + ESEE 50\%) and SLEE exhibited the highest activities with (83.64 and $82.15 \%$, respectively). These results are comparable with the standard (celecoxib) (86.63\%). Also, they displayed higher activities as COX-1 inhibitory percentage activity at $100 \mu \mathrm{g}$ as $72.92 \%$ and $74.35 \%$, respectively, while celecoxib) $(67.64 \%)$. These results are demonstrated in Table 1. Prostaglandins are basic middleman of the body's response to soreness, and inflammatory Consists from essential fatty acids found in cell membranes. This reaction is Stimulate by cyclooxygenase, a membraneassociated enzyme occurring in two isoforms, COX1 and COX-2. Non-steroidal of anti-

$$
\text { inflammatory Medicines (NSAIDs) }
$$

Operate by inhibiting the activity of COX (Taylor $e t$ al., 2002). 
Medhat I.A.E et al., 2020

Table 1. in vitro COX-1 and COX-2 inhibitory activity

\begin{tabular}{cccc}
\hline Sample & Concentration $(\mu \mathrm{g})$ & \multicolumn{2}{c}{ Inhibition $(\%)$} \\
\cline { 3 - 4 } & & COX-1 & COX-2 \\
\hline \multirow{2}{*}{ Ethanolic extract of Stevia } & 100 & 54.35 & 82.15 \\
rebaudiana & 10 & 41.80 & 59.92 \\
(SE) & 1.0 & 32.36 & 43.44 \\
& 0.10 & 66.99 & 38.54 \\
Ethanolic extract of fenugreek (FE) & 100 & 54.17 & 78.74 \\
& 10 & 42.51 & 56.37 \\
Combination composed from & 1 & 35.16 & 46.71 \\
& 0.1 & 72.92 & 35.91 \\
SE 50\% + FE 50\% & 100 & 58.72 & 83.64 \\
& 10 & 41.08 & 61.88 \\
Celecoxib (standard) & 1 & 40.04 & 48.41 \\
& 0.1 & 67.64 & 40.96 \\
& 100 & 53.65 & 86.63 \\
& 10 & 49.80 & 75.26 \\
& 1 & 42.51 & 58.71 \\
\hline
\end{tabular}

Safayhi and Sailer, (1997) reported that diterpenes, triterpenes and pentacyclic triterpenes in inflammatory plants have been act as anti -atory factors. S. rebaudiana as food can treat as diseases immunet system, such as rheumatoid arthritis (Jeong et al., 2010). The anti-inflammatory propertes of fenugreek may be due to existence of flavonoids and saponins. Flavonoids used as antioxidant and inhibitors of cyclooxygenase (COX), and lipoxygenase (Handa et al., 2005; Sharififar et al., 2009).

in vitro cyclooxygenase-II selectivity index (COX1/COX-2):

Table 2. $\mathrm{IC}_{50}$ and S.I of plant extracts against Cox-1 / Cox-2

\begin{tabular}{cccc}
\hline & Cox-1 & Cox-2 & S.I. \\
\cline { 2 - 3 } Sample & $\mathrm{Ic}_{50} \square \mathrm{g} / \mathrm{ml}$ & $\mathrm{Ic}_{50} \square \mathrm{g} / \mathrm{ml}$ & 2.24 \\
Ethanolic extract of fenugreek (FE) & 33.68 & 15.05 & 1.89 \\
Ethanolic extract of Stevia rebaudia(SE) & 23.34 & 12.35 & 2.20 \\
Combination 50\%FE+50\%SE & 16.81 & 7.66 & 8.93 \\
Celecoxib (Stander) & 11.77 & 1.32 & \\
\hline
\end{tabular}

3.2. activity of plant extract as Anti-inflammatory in vivo:

Carrageenan is widely act as an actual example for inflammation-causing paw edema in rats when investigating a new medicine efficacy as an anti-inflammatory. The anti-inflammatory activity of SLEE and FSEE opposite carrageenan-induced hind paw edema has been shown in tables 3 and 4 . In the groups studied, edema volume $(\mathrm{cm})$ was evaluated at different intervals $(0,1,2,3$ and 4 hours). The results in table 3 showed that the injection of carrageenan in rats caused a significant increase $(p<0.05)$ in edema
Data in Table (2) revealed that the most effective treatment is a combination (50\% SLEE + $50 \%$ FSEE, $100 \mu \mathrm{g}$ ), which cause $50 \%$ inhibition of the COX-1 and COX-2 enzyme, compared to standard (Celecoxib).

Cyclooxygenase (COX) is the locate enzyme in prostaglandin synthesis, there are two types, $\mathrm{COX}-1$ is an enzyme found in widely tissues, while COX-2 whose synthesis can be up-regulated by cytokines, and growth agents. (Fosslien, 2000). weight compared to the control group and this was in agreement with the findings of the previous reports (Haddadi and Rashtiani, 2020).

The injection of SLEE and FSEE decreased significantly paw volume $(p<0.05)$, reaching a maximum reduction at the end of the experiment after $4 \mathrm{~h}$, when compared to the carrageenan group (Table 3 ). On the other hand, the edema volume in the combination of (SLEE + FSEE) group (200 
Scientific Journal of Agricultural Sciences 2 (2): 00-00, 2020

Table 3. In vivo- Anti-inflammatory activities of plant extracts and reference drug indomethacin:

Anti

Mean value of paw edema thickness $(\mathrm{cm})$

inflammatory

\begin{tabular}{|c|c|c|c|c|c|c|c|c|c|}
\hline & \multirow[t]{2}{*}{ Normal } & \multirow[t]{2}{*}{ control } & \multirow[t]{2}{*}{ Indo (7mg) } & \multicolumn{2}{|c|}{ ST } & \multicolumn{2}{|c|}{ FE } & \multicolumn{2}{|c|}{$\begin{array}{c}\text { Combination } \\
\text { ST } 50 \% \text { + FE 50\% }\end{array}$} \\
\hline & & & & $200 \mathrm{mg}$ & $400 \mathrm{mg}$ & $200 \mathrm{mg}$ & $400 \mathrm{mg}$ & $\begin{array}{c}100 \mathrm{mg}+1 \\
00 \mathrm{mg}\end{array}$ & $\begin{array}{c}200 \mathrm{mg}+2 \\
00 \mathrm{mg}\end{array}$ \\
\hline \multirow{2}{*}{ Zero time } & \multirow{2}{*}{$0.30^{\mathrm{b}} \pm 0.0$} & $0.72^{\mathrm{a}}$ & $0.71^{\mathrm{a}}$ & $0.71^{\mathrm{a}}$ & $0.73^{\mathrm{a}}$ & $0.71^{\mathrm{a}}$ & $0.71^{\mathrm{a}}$ & $0.71^{\mathrm{a}}$ & $0.73^{\mathrm{a}}$ \\
\hline & & \pm 0.029 & \pm 0.025 & \pm 0.025 & \pm 0.029 & \pm 0.047 & \pm 0.047 & \pm 0.025 & \pm 0.029 \\
\hline \multirow{2}{*}{$1 \mathrm{hr}$} & \multirow{2}{*}{$0.30^{\mathrm{d}} \pm 0.0$} & $0.77^{a}$ & $0.59^{c}$ & $0.66^{b}$ & $0.68^{b}$ & $0.65^{b}$ & $0.64^{b}$ & $0.65^{b}$ & $0.66^{b}$ \\
\hline & & \pm 0.029 & \pm 0.047 & \pm 0.025 & \pm 0.029 & \pm 0.040 & \pm 0.025 & \pm 0.040 & \pm 0.025 \\
\hline \multirow[t]{2}{*}{$2 \mathrm{hr}$} & \multirow{2}{*}{$0.30^{\mathrm{f}} \pm 0.0$} & $0.80^{\mathrm{a}}$ & $0.53^{\mathrm{e}}$ & $0.56^{\mathrm{ed}}$ & $0.65^{b}$ & $0.64^{b}$ & $0.59^{c d}$ & $0.63^{\mathrm{cb}}$ & $0.64^{b}$ \\
\hline & & \pm 0.050 & \pm 0.029 & \pm 0.025 & \pm 0.0 & \pm 0.025 & \pm 0.025 & \pm 0.029 & \pm 0.025 \\
\hline \multirow{2}{*}{3 hr } & \multirow{2}{*}{$0.30^{\mathrm{e}} \pm 0.0$} & $0.80^{\mathrm{a}}$ & $0.49^{d}$ & $0.54^{\mathrm{c}}$ & $0.58^{\mathrm{cb}}$ & $0.56^{\mathrm{cb}}$ & $0.59^{b}$ & $0.54^{\mathrm{c}}$ & $0.55^{\mathrm{cb}}$ \\
\hline & & \pm 0.050 & \pm 0.047 & \pm 0.025 & \pm 0.029 & \pm 0.025 & \pm 0.025 & \pm 0.025 & \pm 0.0 \\
\hline \multirow{2}{*}{$4 \mathrm{hr}$} & \multirow{2}{*}{$\mathbf{0 . 3 0} \pm 0.0$} & $0.83^{a}$ & $0.44^{\mathrm{f}}$ & $0.49^{\mathrm{ed}}$ & $0.54^{c b}$ & $0.53^{c}$ & $0.56^{b}$ & $0.46^{\mathrm{ef}}$ & $\mathbf{0 . 5 1} 1^{\mathrm{cd}}$ \\
\hline & & \pm 0.029 & \pm 0.025 & \pm 0.025 & \pm 0.025 & \pm 0.029 & \pm 0.025 & \pm 0.025 & \pm 0.025 \\
\hline
\end{tabular}

Data represent the mean \pm S.D. Means of various litters within the same row are considerably different at $(\mathrm{P}<0.05)$. 
Medhat I.A.E et al., 2020

Table 4. Percentage of inhibition:

\begin{tabular}{|c|c|c|c|}
\hline Group & Initial paw volume & 4 hr. $(\mathrm{Cm})$ & $\begin{array}{c}\text { Inhibition } \\
\text { percentage }\end{array}$ \\
\hline Control & $0.30 \pm 0.0$ & $0.83^{\mathrm{a}} \pm 0.029$ & --- \\
\hline Indomethacin (7 mg) & $0.30 \pm 0.0$ & $0.44^{\mathrm{f}} \pm 0.025$ & 73.58 \\
\hline 200 & $0.30 \pm 0.0$ & $0.49^{\mathrm{ed}} \pm 0.025$ & 64.14 \\
\hline 400 & $0.30 \pm 0.0$ & $0.54^{\mathrm{cb}} \pm 0.025$ & 54.72 \\
\hline 200 & $0.30 \pm 0.0$ & $0.53^{c} \pm 0.029$ & 56.60 \\
\hline 400 & $0.30 \pm 0.0$ & $0.56^{\mathrm{b}} \pm 0.025$ & 50.94 \\
\hline $\begin{array}{c}\text { Combination ST } 50 \%+\text { FE } 50 \% \\
200 \mathrm{mg}\end{array}$ & $0.30 \pm 0.0$ & $0.46^{\mathrm{ef}} \pm 0.025$ & 69.81 \\
\hline $\begin{array}{c}\text { Combination } \\
\text { ST } 50 \%+\text { FE } 50 \% 400 \mathrm{mg}\end{array}$ & $0.30 \pm 0.0$ & $0.51^{\mathrm{cd}} \pm 0.025$ & 60.38 \\
\hline
\end{tabular}

$\mathrm{mg} / \mathrm{kg} \mathrm{b.wt)} \mathrm{was} \mathrm{significantly} \mathrm{lower} \mathrm{than} \mathrm{the} \mathrm{control}$ and indomethacin groups.

Data in Table 4 indicated that (SLEE + FSEE) at a dose (200 mg/kg b.wt) showed 56.60 and $64.14 \%$, respectively inhibition carrageenan-induced rat paw edema. The inhibition at a dose $(200 \mathrm{mg} / \mathrm{kg}$ b.wt) showed anti-inflammatory activity compared to a dose $(400 \mathrm{mg} / \mathrm{kg}$ of b.wt) that appeared 50.94 and $54.72 \%$, respectively inhibition of carrageenaninduced rat paw edema.

The results also showed that the combination of (SLEE + FSEE) with a concentration $(200 \mathrm{mg} / \mathrm{kg}$ b.wt) showed $69.81 \%$ inhibition of carrageenaninduced rat paw edema. This result indicated that the mixture SLEE and FSEE at this concentration (200 $\mathrm{mg} / \mathrm{kg} \mathrm{b.wt)} \mathrm{showed} \mathrm{a} \mathrm{maximum} \mathrm{anti-inflammatory}$ activity compared to the mixture of (SLEE and FSEE) with a concentration $(400 \mathrm{mg} / \mathrm{kg}$ b.wt), which showed only $60.38 \%$ inhibition of carrageenan-induced rat paw edema.

Inflammatory is the response of living tissue to deteriorate, which involves activating various enzymes, moderators freeing, cell emigration, tissue separated, and repair (Katzung, 2004). The first stage of edema is attributed to the emancipation of histamine and 5-hydroxytryptamine. (Balasubramanian et al., 2005).

These results were in agreement with Arya et al., (2012) that SLEE at the test doses 100, 200 and $400 \mathrm{mg} / \mathrm{kg}$ body weight reduced the edema induced by carrageenan by 28,37 and $42 \%$, respectively at 4 h. The Fenugreek seeds' excerpt could also inhibit paw-edema, indicating their prominent mechanism of inhibitory effects on prostaglandins and bradykinin, which are responsible for the second stage of edema (Yoshimoto et al., 1983). Rehman and Ghauri, (2018) reported that the results of the study fenugreek (Trigonella foenum-graecum L.) are decrease (85\%) inflammatory of the paw in formaldehyde and carrageenan-induced paw edema. This inhibitory activity may be due to the natural phenolic and flavonoid compounds, which play antioxidants activities by different mechanisms. The high contents of these phytochemicals in both extracts can exhibit anti-inflammatory activity (Bairagi et al., 2012). Flavonoids frustrate Cox-I enzymes contributory in the initiation stage of inflammation reactions (Dames et al., 1985).

\section{CONCLUSION}

Recent studies have reported that Trigonella foenum-graecum L. (Fenugreek) seed extracts had potential anticancer properties (Nagulapalli et al., 2017). Our findings indicated that the SLEE and FSEE can be used to as anti-inflammatory agent to reduce inflammation alleviate pain. The results demonstrated that these plants may play an important role for discovering new anti-inflammatory natural drugs. Also, these medicinal plants can be subjected to further investigations as anticancer natural products.

\section{REFERENCES}

Arya A, Kumar S, Kasana M (2012). Antiinflammatory activity of in vitro regenerated calli and in vivo plant of Stevia rebaudiana (Bert.) Bertoni. International Journal of Scientific and Research Publications, 2(8): 435-439.

Assaf HK, Nafady AM, Allam AE, Hamed ANE, Kamel MS (2019). Promising antidiabetic and wound healing activities of Forsskaolea tenacissima L. aerial parts. Journal of Advanced Biomedical and Pharmaceutical Sciences, 2(2): 72-76.

Bairagi SM, Aher AA, Nema N, Nimase PK (2012). Anti-inflammatory evaluation of methanol extract and aqueous fraction of the bark of Bauhinia variegata (Leguminosae). International Journal of Research in Pharmacy and Chemistry, 2(1): 77-82.

Balasubramanian A, Ramalingam K, Krishnan S, Christina AJM (2005). Anti-inflammatory Activity of Morus indica Linn., Iranian Journal of Pharmacology, 4(1): 13-15. 
Dames J, Bourdon V, Remacle-Uolon G, Lecomte J (1985). Pro-inflammatory flavonoids which are inhibitors of prostaglandin biosynthesis. Prostaglandins, Leukotrienes and Medicine, 19(1): 11-24.

Debnath $M$ (2008). Clonal propagation and antimicrobial activity of an endemic medicinal plant Stevia rebaudiana. Journal of Medicinal Plants Research, 2(2): 45-51.

Deraedt R, Jouquey S, Benzoni J, Peterfalvi M (1976). Inhibition of prostaglandin biosynthesis by non-narcotic analgesic drugs. Archives Internationales de Pharmacodynamie et de Thérapie, 224(1): 30-42.

Fosslien, E. (2000). Biochemistry of cyclooxygenase (COX)-2 inhibitors and molecular pathology of COX-2 in neoplasia. Critical reviews in clinical laboratory sciences, 37(5), 431-502.

Ghorab MM, ElGaby MSA, Alsaid MS, Elshaier YAM, Soliman AM, Elsenduny FF, Badria FA, Sherif AYA (2017). Novel Thiourea Derivative Bearing Sulfonamide Moiety as Anticancer Agents through COX- 2 inhibition. Anti-cancer Agents in Medicinal Chemistry, 17): 1411-1425.

Gupta E, Purwar S, Sundaram S, Rai GK (2013). Nutritional and therapeutic values of Stevia rebaudiana: A review. Journal of Medicinal Plants Research, 7(46): 3343-3353.

Haddadi R, Rashtiani R (2020). Anti-inflammatory and anti-hyperalgesic effects of milnacipran in inflamed rats: involvement of myeloperoxidase activity, cytokines and oxidative/nitrosative stress. Inflammopharmacology, 28, 903-913.

Handa T, Yamaguchi K, Sono Y, Yazawa K (2005). Effects of fenugreek seed extract in obese mice fed a high-fat diet. Bioscience, Biotechnology, and Biochemistry, 69(6): 1186-1188.

Howlader MMS, Ahmed SR, Kubra K, Bhuiyan MKH (2016). Biochemical and phytochemical evaluation of Stevia rebaudiana. Asian Journal of Medical and Biological Research, 2(1): 121-130.

Jain A, Sharma S, Goyal M, Dubey S, Jain S, Sahu J, Kaushik A (2010). Anti-inflammatory activity of Syzygium cumini leaves. International Journal of Phytomedicine, 2(2): 124-126.

Jeong IY, Lee HJ, Jin CH, Park YD, Choi DS, Kang MA (2010). Anti-inflammatory activity of Stevia rebaudiana in LPS-induced RAW 264.7 cells. Preventive Nutrition and Food Science, 15(1): 14-18. Katzung BG (2004). Basic and Clinical pharmacology, $9^{\text {th }} \mathrm{Ed}$ adrenocorticosteroid and adrenocortical antagonists. McGraw Hill, London. 2004: 641-646.

Kulkarni SK (2007). Hand book of experimental pharmacology Vallabh prakashan, New Delhi.

Mahmood MN, Yahya IK (2017). Nutrient and Phytochemical of Fenugreek (Trigonella Foenum graecum) Seeds. International Journal of Sciences: Basic and Applied Research (IJSBAR), 36(3), 203213.

Mahmoud BK, Hamed ANE, Samy MN, Mostafa EM, Wanas AS, Radwan MM, Elsohly MA, Kamel MS (2019). Phytochemical and antimicrobial studies of Markhamia platycalyx (Baker) Sprague leaves. Tropical Journal of Pharmaceutical Research, 18(12): 2623-2631.

Mehrafarin A, Qaderi A, Rezazadeh S, Badi HN, Noormohammadi Gh, Zand E (2010). Bioengineering of Important Secondary Metabolites and Metabolic Pathways in Fenugreek (Trigonella foenum-graecum L.). Journal of Medicinal Plants, 9(35): 1-18.

Mohammed MHH, Hamed ANE, Khalil HE, Kamel MS (2016). Phytochemical and pharmacological studies of Citharexylum quadrangulare Jacq. leaves. Journal of Medicinal Plants Research, 10(18): 232-241.

Mondal A, Maity TK, Bishayee A (2019). Analgesic and Anti-Inflammatory Activities of Quercetin-3-methoxy-4'-glucosyl-7-glucoside

Isolated from Indian Medicinal Plant Melothria heterophylla. Medicines, 6(2), 59.

Nagulapalli Venkata KC, Swaroop A, Bagchi D, Bishayee A (2017). A small plant with big benefits: Fenugreek (Trigonella foenum-graecum Linn.) for disease prevention and health promotion. Molecular nutrition \& food research, 61(6), 1600950.

Perez C, Pauli M, Bazerque P (1990). An antibiotic assay by the agar well diffusion method. Acta Biologiae et Medicine Experimentalis, 15: 113-115.

Rehman T, Ghauri AO (2018). Nutritional and health benefits of fenugreek: A short review, International Journal of Homoeopathic Sciences, 2(2): 28-30.

Safayhi H, Sailer ER (1997). Anti-inflammatory actions of pentacyclic triterpenes. Planta Medica, 63(06): 487-493.

Sharififara F, Khazaeli P, Alli $\mathbf{N}$ (2009). In vivo evaluation of anti-inflammatory activity of topical preparations from Fenugreek (Trigonella foenumgraecum L.) seeds in a cream base. Iranian Journal of Pharmaceutical Sciences, 5(3): 157-162.

Taylor JLS, van Staden J, Jäger AK (2002). COX1 and COX-2 inhibitory activity in extracts prepared from Eucomis species, with further reference to extracts from E. autumnalis autumnalis. South African Journal of Botany, 68(1): 80-85.

Vane JR, Botting RM (1995). New insights into the mode of action of anti-inflammatory drugs. Inflammation Research, 44(1): 1-10.

Wahid A, Hamed AN, Eltahir HM, Abouzied MM (2016). Hepatoprotective activity of ethanolic extract of Salix subserrata against $\mathrm{CCl}_{4}$-induced chronic 
Medhat I.A.E et al., 2020

hepatotoxicity in rats. BMC Complementary and Alternative Medicine, 16: 263.

Yazdinezhad A, Andalib S (2017). Effect of Fulcaria vulgaris hydro-alcoholic extract on carrageenan-induced paw edema in rats. Research Journal of Pharmacognosy, 4(Supplement), 19-19.
Yoshimoto T, Furukawa M, Yamamoto S, Horie T, Watanabe-Kohno S (1983). Flavonoids: Potent inhibition of archidonate lipoxygenase, Biochem. Biochemical and Biophysical Research Communications, 116(2): 612-618.

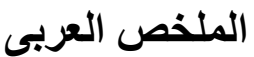

\section{قياس النشاط المضاد للالتهابات معملياً و داخل الانسجة الحية للمستخلصات الإيثانولي للاستفيا و الحلبة}

مدحت إبراهيم احمد الطيب1, جمال فخري عبد النعيم²، ياسر عبدالصبور محمد خليفه 1، هريدي حسن هريدي3

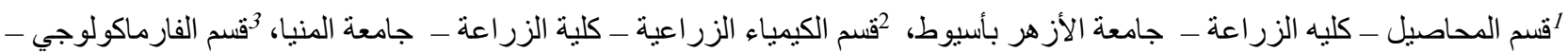
كليه الطب - جامعة الأزهر بأسيوط الزئ

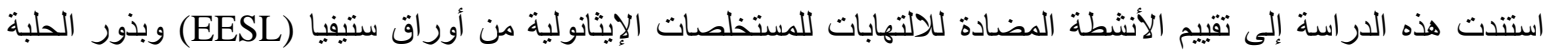

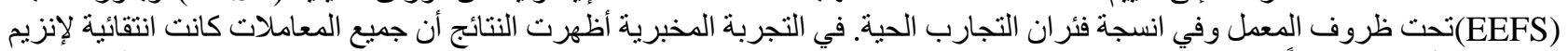

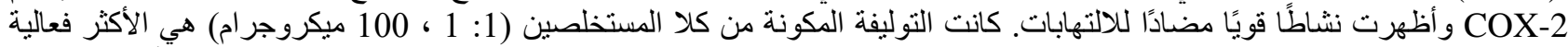

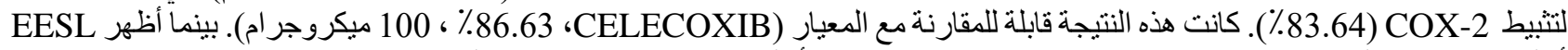

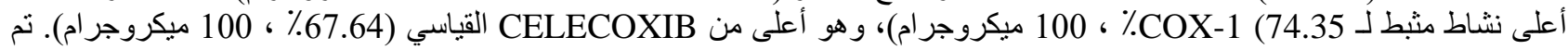

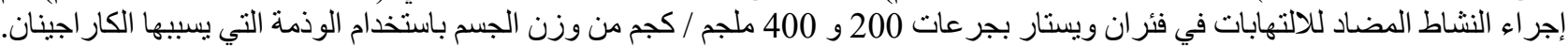

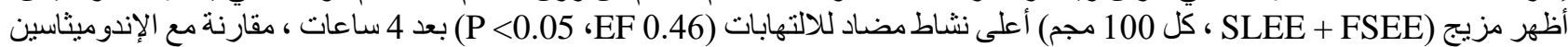

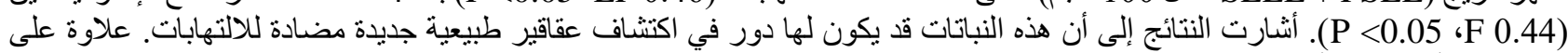
ذللك، يمكن أن تخضع أور اق الاستيفيا وبذور الحلبة لمزيد من الدر استات كعو امل مضادة للسرطان. 